is made sufficiently boldly, so far as depth is concerned, the finger will readily enter the urethra, and then may be passed on into the bladder. On the withdrawal of the finger the tube is then to be substituted. It is seldom under these circunistances that a grooved staff can be introduced into the bladder by the urethra. A stricture rarely occasions an abscess behind it so long as it remains permeable to an instrument or to urine otherwise than in drops. The operation is seldom attended with hremorrhage when it is executed precisely and cleanly. If the bleeding is free, one of Buckston Brown's tampons may be substituted temporarily for the other tube. Before the finger is withdrawn from the bladder and the tube introduced, advantage should be taken to explore the interior of the viscus, forcible pressure being exercised above the pubes with the other hand so as to bring the bladder within reach. In many cases of long-stauding stricture, where the bladder has undergone structural changes, I have thus incidentally been able to obtain information which was of value in the future management of the case. In two instances I removed phosphatic concretions from off the mucous membrane which might have formed nuclei for stone. What I have described closely resembles Cock's operation of tapping the urethra at the apex of the prostate; it may, in fact, be said to be an adaptation of it for treating retention of urine complicated with stricture and urinary abscess, with extravasation of urine impending or commencing. I usually retain the tube in the bladder for about a week, or until the perineal wound $h t s$ commenced to clean and all sloughs have been discharged. The stricture should then be explored from the meatus. In some instances it will be found that the abscess has converted what was previously a tight impassable stricture into one that will admit of dilatation by bougies. I have thus succeeded in eventually obtaining a full-sized urethra, with occlusion of the perineal incision, as in Syme's operation. In other cases 1 have found the stricture unanenable to management of this kind, and have treated it by section, either from within or without; whilst in a few the urethra has been found so extensively disorganised that the patient has been glad to exchange his previous condition of stricture and discomfort for one of perineal fistula and comparative ease in accordance with the excellent practice of $\mathrm{Mr}$. Cock. In cases where extravasation has also taken place and the skin is undermined with sloughs and pus, it is a matter of considerable importance to know that whatever sinuses there may be connected with the urethra along which fluids may burrow, there is a direct escape for urine from the bladder which cannot be inter. fered with, and that consequently no further extravasation unknown to the surgeon is likely to take place.

I may here observe how desirable it is that any incision practised upon the perineum for an inflammatory swelling should be confined to the median line, as indicated by the raphe. It sometimes happens that the perineal tumefaction occasioned by a stricture and resulting in abscess is by no means central; on the contrary, cases are frequently met with where the formation is lateral, and may be traced in the direction of one side or other of the pubic arch, the matter making its way in the interval between the muscles and in contact with one of the crura penis. Still under these circumstances the incision must correspond with the raphe, otherwise hremorrhage and permaneut fistulx may be the result. Though the most prominent point of the swelling may not always correspond with the incision, the abscess cavity or extravasation is almost invariably opened into with the knife as the urethra is approached, or, if necessary, may bo reached with the finger or dressing forceps. In incising the perineum for abscess or extravasation I have always regretted any departure from the rule I have thus formulated for my own guidance. An absce:s or a deep extravasation, though taking origin from a centrally situated stricture which has caused the urethra to give way, can occasion a lateral tumefaction which may mislead. I will illustrate these observations by some brief notes of cases, premising, to sare repetition, that they were all instances of long-standing subpubic stricture of the urethra occurring in middle-aged men in my practice in the Royal Infirmary; these came under notice within a short period of each other, and formed material for clinical remarks at the time.

CASE 1.-A. B - had been almost unable to pass any urine for six days, when he noticed a hard swelling behind his scrotum. He had had a rigor before his admission into the infirmary. On admission nothing but a filiform instru. ment could be passed. The perineum was hard and bulging, and the region of the bladder was exceedingly tense, I opened the perineum with a deep incision, which enabled me to pass my finger into the membranous urethra, and on into the bladder. A quantity of fetid pus and urine was discharged. A tube was introduced into the bladder through the wound and secured in the manner that has been described. By this arrangement bladder drainage was carried out. Seven days afterwards I removed the tube and passed a small bougie along the whole length of the urethra. I felt sure from the feel of the stricture that dilatation conld now be proceeded with without difficulty. In a month the perineal wound had closed and the patient left the infirmary passing a full-sized bougie for himself. He remains well though he occasionally passes an instrument for himself.

CASE 2.-In many respects similar to the preceding, but some extravasation of urine into the scrotum and penis had taken place before I saw this patient. The practice adopted was the same as in Case 1, with the addition of Incisions where extravasation had taken place. At the end of eight days I removed the tube and subsequently tried gradua dilatation of the stricture, but without any progress. As the stricture was tight and contractile, but at the same time limited, I performed internal urethrotomy with Maisonneuve's instrument, after which quite as good progress was made as in the previous instance.

CASE 3.-Here, in addition to an enormous urinary abscess, there was extensive extravasation of urine, the root of the penis being occupied by a dense cicatricial mass, the result of an old liceration with a cotton hook. With a perineal tube, and free incisions wherever there was ex. travasation, and plenty of support, with good nursing, he made excellent progress, but I was never able to establish the continuity of the urethra. I therefore left him, as in Cock's operation, to micturate through his perineum, an exchange which he has never regretted. He has no desire to return to the previous condition of wretchedness which his dense stricture entailed upon him.

My observations lead me to the following conclusions:1. That in all cases of perineal abscess and extravasation of urine associated with organic stricture of the urethra perineal urethrotomy behind the stricture should be practised, and provision made for the direct escape of urine by the insertion of a tube into the bladder from the wound 2. That the treatment of the stricture should be postponed until the more urgent symptoms of abscess and retention, or extravasation of urine, have been relieved.

\section{CASE OF FIBROUS PAPILLOMA OF THE FEMALE BLADDER SUCCESSFULLY} TREATED BY OPERATION.

\section{By FREDERIC THORNE, M.R.C.S., \&c.}

ON June 18th, 1881, I received an urgent summons from a lady, aged twenty-eight, and unmarried, who had passed a considerable quantity of dark porter-coloured urine. This, upon inquiry, had occurred twice before at intervals of twelve months, but as the general health was not in any way affected no notice was taken of it. On examining the water with the microscope I found, as I thought, a large quantity of hæmatin, but few blood cells, and imagined the case to be one of hematinuria; but as I had to convey the specimen in warm weather a distance of twenty-five miles, I now conclude that this appearance was due to commencing decomposition. The hæmorrbage yielded to internal treat. ment by astringents, but relapses occurred at intervals of a few weeks until January last. The bleeding then increased in quantity and frequency, and soon became constant, being accompinied by all the distressing sroptoms of cystitis. The bladder was examined fur stone. tailing to find which I proposed to dilate the urethra, if only as a means of diagnosis, on the ground that the symptoms justified a suspicion of the existence of some form of papillary disease. My diagnosis was not supported by others who were con. sulted, the prevailing opinion being that the case was one of tubercular ulceration of the bladder, and it was decided to use injections. These were continued until May, blood being always present in variable quantity in the urine.

I may here mention that the only injection which had an! 
eflect in controlling the hæmorrhage was one containing fiteen grains of alum to the ounce of water. Meanwhile I hiul become more and more suspicious of the existence of some morbid growth, and was confirmed in my opinion by that of Dr. W. Roberts, to whom I sent some specimens of the urine. On May 24 th he wrote to me as follows: "The deposic contains large numbers of round-tailed and spindle- hapel cells, deeply stained with hrematin. Mingled with these are numbers of red blood discs, mostly of withered appearance, but infinitely few in proportion to the deep colouration of the urine. This point reminds me of the state of the urine in cases of intermittent hæmatinuria ........ My impression at present is that there exists one or more polypoid crowths."

Early in June I found in the urinary deposit a small flesby particle the size of a small pea, in which, under the microscope, I could distinctly trace bloodressels. An operation was now sanctioned, and on $\mathrm{July} \mathrm{llth}$, the patient, having been placed under the influence of chloroform, I rapidly dilated the urethra, and found, just within reach of my finger, a large sof mass growing from a pedicle attached to the base of the bladder. Seizing this with forceps, I dragged it, with a vortion of the bladder, through the urethra, transfixed the pedicle with two sharp hooks, and separated it with scissors. Some adjacent rough patches were removed with the curette, and the stump was freely swabbed with tincture of iodine, and, all bleeding having ceased, returned into the bladder, which was then injected with iced water, with about 30 per cent, of tincture of iodine. By this means another mass nearly as large as the one removed was washed out, it baving probably been detached during my efforts to pull the tumour through the urethra. The size of the entire growth was about that of a tennis-ball. After the operation the natient passed water naturally every four to six hours. The temperature and pulse were normal throughout, and all trace of blood disappeared on the fifth day. She progressed favourably until July 21 st, when at $4 \mathrm{~A}$. M. violent hæmorrhage commenced, the bladder evacuating large clots every fen minutes. Ice was applied over the lower abdomen, and introduced into the vagina, injections of iced water and tincture of perchloride of iron were used, but no means availed to control the bleeding until gallic acid in doses of forty grains, twice repeated, were administered. The first dose was vomited. I adopted this course, having found it immediately effectual in severe hæmorrhage after extraction of a tooth. No recurrence of bleeding took place, and with the exception of great exhaustion and some anæmia the patient's recovery from this time was uninterrupted. $\mathrm{Mr}$. Butlin kindly examined a portion of the growth for me, and describes it as "a very good specimen of papilloma with a fibrous basis." "It appears," says he, "to be much larger than is usually the case." I believe this disease is very rarely met with in so young a subject, but I am strongly of opinion that in all obscure cases of hæmaturia in the female rapid dilatation of the urethra as a diagnostic measure should be resorted to. I have never known any permanent inconvenience result from such dilatation, for whatever purpose adopted; and it is evident that if such means had been earlier agreed to in this case my patient would have been saved much misery and suffering, and some considerable risk to life from the repeated and long continued hemorrhages which occurred.

Leamington.

A meTING in connexion with the proposed Convalescent Home at Clacton-on-Sea was held on the 2 nd inst. in the Sbire Hall, Chelmsford, to consider the trusts proposed to be inscrted in the deed relative to the Home. It was arranged that inmates should pay ten shillings per week toweds their maintenance, that a separate cottage for the reception of persons who have been suffering from infectious disorder be attached to the Home, and that the Home be lianded over to the Nursing Institution finished, furnished, and free from all debt. The trusts gave power to mortgage the property, sell it, purchase other land and to invest any money the trustees might possess in Bank stock, India stock, or in the County stock to be issued under the Essex County Loans Act.

AT the quarterly meeting of the Directors of the Saval Medical Supplemental Fund, held on the 9 th inst., Sir IV. E. Smart, K C.B., M.D., Inspector-General, in the chair, the sum of $£ 54$ was distributed among the several aprlicant:

\section{g thitror}

\section{HOSPITAL PRACTICE, BRITISH AND FOREIGN.}

Nulla autem est alia pro certo noscendivia, nisi quamplurimas et morbornm et dissectionum historias, tum aliorum tum proprias collectas habere, et inter se comparare.-Morgagni De Sed. et Caus. Morb., lib. iv. Proœmium.

\section{UNIVERSITY COLLEGE HOSPITAL.}

TWO CASES OF CALCULUS OF OXALATE AND PHOSPHATE OF LTME REMOVED BY LITHOTRITY AT A SINGLE SITTING; SINGULARIY LONG DURATION OF SYMPTOMS, WITH REMARKS UPON AN IMPROYED CLOVER'S EVACUATING BOTTLE.

(Under the care of Mr. BERKELEY HILL.)

CASE 1.-C. B-, aged twenty, painter, was admitted on June 20th, 1882. Had passed urine in bed every night during sleep from five years old till about one year ago. Pain at end of the penis had been severe at times after passing water since he was eight years old. For some years the pain had not lasted more than a few seconds. When he had a cold he had pain also above the bladder. As long as six years ago bad calls to void urine every two hours by day, but only once by night. Riding in a country cart made no difference. When about eight years old he would pass blood with his urine, sometimes as much as a teaspoonful ; this happened about every two or three months. Most of the blood came after the urine. When admitted the blood never exceeded two or three drops at a time. Running or jumping caused blood to flow after passing water and the pain is greater on such occasion. The urine had been habitually cloudy. In other respects his health had always been excellent.

On admission the urine was found to be free from blood, acid, sp. gr. 1020, and depositing a large amount of phosphates, with some mucus. On sounding, a small calculus was struck.

On June 28th the patient was put under ether, and a small very hard stone was crushed, and the débris removed by means of a modification of Clover's wash-bottle. The patient vomited a little after the operation, and that evening the temperature rose at 8.30 P.M. to $100 \cdot 2^{\circ} \mathrm{F}$. falling in the night to normal range, and again rising to $100.4^{\circ} \mathrm{F}$. at noon on the 29th. Thenceforth his convalescence was uninterrupted. The patient slept well, felt little pain in passing water, and the urine charged with blood for two days became free on July lst. It also gradually lost its mucous turbidity, and could be retained for six hours without distress.

On July 11 th he was carefully sounded, and no stone was felt. On the 15th, having been up for six days walking about the ward, he was discharged. The débris of the calculus (part having been inadvertently lost) weighed thirty-five grains, and consisted chemically of phosphate and oxalate of lime. No uric acid was found.

CASE 2.-T. M- aged twenty-two, was admitted June 22nd, 1882. From early childhood up to thirteen years old the patient used to pass urine frequently into his trousers or in bed. He had no pain then. Of late he had had to rise once or twice at night. The stream often suddenly stopped ; it then would dribble, and thus became again free. This caused no pain. Four years ago, without apparent cause, the patient had an attack of great frequency of micturition, and the urine, which was blood-stained, dribbled away. Pain was felt at the end of the penis in the attack. After this attack passed off the patient was for three years singularly well, passing water three or four times a day and once or twice at night. In this period the stream occasionally stopped suddenly, and the evacuation of the bladder was finished by dribbling, but there was no pain connected with the act. On the lith the micturition again became frequent, very little urine passing at a time, and only by straining. No pain after passing urine, and no blood in it. This condition became worse, and he applied for relief as an out-patient. The urine was examined, and much albumen fonnd, so no sound was passed.

On admission, rest in bed for a few days removed the straining de:ire to pass urine, and the albumen almost dis. 